\title{
Children's books for minorities in Poland
}

\author{
ELZBIETA BARBARA ZYBERT
}

University of Warsaw, Dept. of Information and Book Studies, Nowy Swiat 69, 00-046 Warsaw, Poland, e-mail: JAZYBERT@PLEARN.EDU.PL

\begin{abstract}
The paper consists of three parts:

Parts one and two analyze and describe the communicative and therapeutic functions that concem children and adolescents in multicultural settings in Poland.

Publishing activities offfor ethnic minority groups are presented: books and periodicals specially addressed to young readers; libraries (both public and those created by national associations) collecting publications and serving ethnic users. The role and situation of ethnic schools and their libraries are also discussed.

Part three presents a picture of ethnic and national minorities in Polish literature for children and the youth. Special attention is paid to Cypsies, Cermans, and Jews.
\end{abstract}

One of the features characterising the last decades of the 20th century is a tendency to protect and develop the human rights democracy. We observe

firstly, a growing interest in the culture of other people and communities,

secondly, a common acceptance of equality of rights, also concerning different cultures, and -thirdly, an acknowledgement that each culture can significantly contribute to human cultural heritage.

Also a desire for finding out one's own roots and learning the mother tongue is also widely noticeable. According to available data the number of people considering themselves to belong to ethnic minorities is estimated at 2-4\% (800-1.600 thousand) of the total population in Poland.

Books and the printed word take an important place in our lives today. A significant role is ascribed to these carriers of information in a multi-cultural community. The book is a self-contained communication system which functions within the culture system of a given community and which is capable of satisfying the basic needs of the community.

I will focus on two basic book functions that concern children and adolescents in the multiethnic setting, namely:

- the communicative function, and

- the therapeutic function.

Education for All: Culture, Reading and Information, IASL, 1998 
The communicative function covers particular links of the communication process, i.e. the creators of book expression, organizers of book circulation and its readers. The book itself is a material means of recording and transmitting culture contents. Among the institutions that play an important part in educating society are publishing houses, bookstores, libraries and schools. All of them are fundamental in organizing the communicative circulation of books.

Publishing activity is an important element of culture of ethnic minorities. Each of the associations active in 1994 emphasized the significance of this form of activity. It resulted in a number of books and periodicals of varied scope and range of influence. In greater part they were supported financially by the Ministry of Culture. These books were published both in national languages and in Polish.

Among the Belorussian books for children Wiktor Szwed's works deserve particular interest. He is the only poet living in Poland who writes for children in Belorussian. He has published, among other works, a volume of poems 'Przyjann' (Friendship) (1976) and 'Tecza' (Rainbow) (1991) addressed to his daughter, Natalia. His works are influenced by both Polish and Belorussian literature. His poems depict everyday life of children and their games, illustrate appropriate and efficient behavior in various situations, condemn undesired personality traits, and appeal to children to love nature. Poems expressing patriotism, e.g. 'Jestem malenkim Bialorusinem' (I am a little Belorussian), are also significant (Zaniewska 1992,111-130). Short stories for children and occasional poems written by him are regularly published in the yearly 'Blahovist'.

An anthology of poems and stories for children 'Moj rodzinny kat', published in 1963, can be found in libraries and home collections.. Another popular book, still a favorite among Belorussian children, is a collection of fairy-tales and legends ' $\mathrm{O} c z y m$ szumi Puszcza Bialowieska' edited by Mikolaj Hajduk, published in 1982.

Between 1956 and 1991 altogether 134 books in Belorussian were published in Poland. Additionally, translations of 17 short literary works (poems, stories) were published in Polish magazines for children, and 4 books by Belorussian authors (Maksim Tanek, Pawel Kowalou, Janek Bryl, Wiktor Szwed).

Since 1989 the Kashubians have published 10 books for children in both Kashubian and Polish. Those in Kashubian included mainly tales, fables, legends and other pieces of Kashubian origin, but also works devoted to their history and everyday life.

Giants called 'stolems' and dwarfs called 'littlans' or 'krocnieta' frequently appear in the Kashubian mythology. Tales deal with magical animals and other creatures, with magicians and witches; they are also about people's struggle against devils, ghosts, apparitions and the like. This is a world full of fantasy which, nevertheless, contains elements of authentic historical events. Before 1989 collections of poems for children were also published by this association. They were written either in Kashubian only or in the bilingual version.

The Ukrainian minority have published relatively few books for children. One of them is a selection of texts published by the Lemek Society entitled Mamo kup mi knyzku (Mummy, get me a book). The Nicholas Copernicus University has published Na przeleczy Swiatow. 150 ukrainskich basni, gadek, humoresek i podan ludowych - collection of tales, legends and scare stories addressed to Ukrainian and other interested readers. Apart from the books published in Poland Ukrainian children have also access to books published in Kiev, 
e.g. Ukrainski narodni kazki (National Ukrainian tales) for older children, Zolota kniga kazok (A golden book of tales) or historical novels.

There are very few books addressed to Jewish children and youth on the market. Therefore it is worth mentioning the publication of a book (Legendy zydowskie) that should be of interest not only to children but also to adults of various ethnic and national groups. Its author, Louis Ginzberg, is a outstanding researcher of the Bible, an expert in talmudic literature and Jewish humor. His book includes legends, tales and myths that originated in various countries and cultures over about one thousand and five hundred years.

The periodicals are considerably varied. The most popular ones are those that deal with everyday problems, inform about current events, remind of important dates and facts.

Among the 50 registered magazines published by the minority groups only 2 are addressed to children and adolescents. These are the Ukrainian/Lemek Switanok, a bimonthly supplement to the weekly Nasze Slowo, and the Jewish Jidele-Pismo Mlodzezy Zydowskiej i jej przyjaciol. Other groups address children only on selected pages in their journals and magazines that are published for the general minority public. E.g. the Belorussian Niwa devotes for children only one page called 'Zorka'. There, Wiktor Szwed's poems have been published for over 30 years and so the symbol of light and joy provides material for infants and little children. It is very popular among children and is also a precious aid for teachers in teaching Belorussian (Jaroszewicz, 1994, 146). The Belorussian students' periodical Sustreczy (Meetings), which used to be a separate magazine, is now published occasionally as a supplement to the Czasopis.

Among the books addressed to the minorities school textbooks hold an important position. Their publication is financed by the Ministry of National Education. In 1997 the School and Pedagogical Publishing House published 23 titles of books for the Lithuanian, Ukrainian, Belorussian, and Slovak minorities. This is not a complete picture of the situation since, for economical reasons, many textbooks are printed in Lithuania, the Ukraine, Belorussia, and Slovakia but information on their numbers is not provided officially. Representatives of ethnic groups complain about the insufficient number of textbook titles. Those that are in use are often outdated so teachers have to make use of the articles found in the minority media, as is the case with the Belorussian Niwa. Moreover, textbooks for learning foreign languages addressed to general public are also published. Part of school textbooks used in the minority schools come from the native countries of particular groups. Due to the limited number of publications in minority languages school textbooks popularize not only national classical literature but also modern works. The textbook for teaching Belorussian in the 8th form Bialoruska Skarbnica (in which W. Szwed's works are included) is a good example to illustrate the situation. On the basis of the data presented above we can see that the publishing activity of the minorities in Poland is not extensive. This should be an object of worry since early contacts with the printed word may largely determine the child's later attitudes to the book and the problems connected with national identity.

According to Papuzinska (Papuzinska, 1991, 46) functioning of the children's book in multi-ethnic settings depends on the character of relationships that hold among language groups, which result in the status of particular languages in the given society or country. 
Historically, the children's book has usually been a carrier of the dominant culture and written in the language recognized as national or official.

Minority associations in Poland establish their own libraries and cultural centers making books and periodicals in their languages available to readers. In 1994 they amounted to about 75 , and were run mainly by the German, Ukrainian and Czech/Slovak societies.

Research shows that book collections in these libraries are gathered in a random fashion (Hollender, 1995, 49-63) and are mostly donations. Literature for children and the youth makes small percentages of the collections. The unfavorable situation is particularly acute with those minorities which, particularly in the previous years, could not get books from the countries of origin, e.g. Lithuania and Belorussia, the more so that books published there were mostly in Russian, and not in the national languages. A much better situation was, and still is, among the groups that could get relevant publications from abroad, e.g. from Czechoslovakia or Germany. This fact not only influenced the present size of collections but also allowed updating them. This refers to the literature for young readers, especially that the position of relevant literature in the two above-mentioned countries has been good. Moreover, translations from those languages were published by Polish publishing houses and were available in public libraries.

Professional librarians are rarely employed in minority libraries. Those working in them are volunteers, doing community service. Therefore these libraries lack information sources, such as catalogues or files. Their basic activity is confined to lending. They do not provide special activities addressed to children to promote reading, except for organizing occasional meetings, national songs singing, and the like. Language learning and contact with national culture is propagated by cultural centers and common rooms rather than by libraries.

Research into multiethnic collections in Polish public libraries shows that they make a relatively small percentage of the total collection. They lack children's books, in particular. In some public libraries collections concerning the given region are subsumed under ethnic collections thus the size of the collection appears larger. The greatest numbers of books among the ethnic collections are those written in German. This is due to the fact that German is included in the curricula of many schools operating in the regions inhabited by people of German origin. Consequently, there is substantial literature in German, including books and periodicals for children. Other libraries, apart from some exceptions which I will discuss later in connection with the therapeutic role of the book, in addition to lending restrict their activities to book exhibitions and expositions of works by minority artists and children. They also let amateur groups use their premises to perform, and sometimes help in organizing cultural events as e.g. the Lemek Culture Festival 'Watra', held annually.

A crucial role in the formation of national and ethnic awareness is played by education. Education in a minority language has always helped to preserve the minority language and culture patterns. In the past, for this reason, Polish governments used to consistently eliminate minority schools.

At present it is becoming increasingly popular enable minority group children grow up a bilingual situation. It helps them preserve cultural continuity at the school-minority group interface. The child who speaks a minority language at a school where the official state language is used feels psychological and intellectual discomfort. Bilingual education also 
enables the child to understand that there are different forms of verbal behavior and ways of expressing emotions and thoughts, which fosters the development of tolerant attitudes toward other national groups and cultures. Research carried out by Lambert confirms the claim that bilingual children have a more objective and tolerant attitude to other communities than monolingual children have (Aleksander, 1992, 61-62).

At present teaching the national language of the minority is provided at the parents' request an is in force until the child leaves school (or kindergarten). Education takes place in:

schools and kindergartens with pupils' native language of instruction,

bilingual schools and kindergartens,

schools with extra instruction in a minority language,

inter-school groups with instruction in a minority language.

During the school-year $1996 / 97$ the national language of minorities was taught in 440 schools at the elementary and secondary levels. There were 640 teachers 32078 pupils in these schools. For comparison, in 1994/95 the corresponding numbers were: 305 schools, 197 teachers and 13365 pupils (Materialy statystyczne.., 1997).

The largest number of schools with the national language of instruction are those run by the German minority (265 schools), Ukrainian (91) and Belorussian (48). Figures for other minorities and ethnic groups are: Lithuanian - 18 schools, Slovak -15 , Kashubian - 3. In addition the Ukrainian Union provides national language teaching in 70 institutions. Also, besides classes with the national language, there are experimental classes (I-III forms) for Rom children in which requirements are deliberately lowered to enable the pupils to continue education later (Mniejszosci narodowe.., 1995, 20-21).

At the moment there are no schools in which Hebrew or Yiddish is the language of instruction. In 1994 at the initiative of the Ronald Lauder Foundation a private school was established in Warsaw in which Hebrew is taught. The school is for both Jewish and non-Jewish children. It is supported by the Ministry of National Education. The same Foundation carries out educational and religious activities among Jewish children and teenagers.

The school libraries that provide services to children in multiethnic communities are of two kinds:

those operating in ordinary schools which are attended by both Polish and minority group children (classes with an extended program of teaching the national language are often formed in there),

those in schools for particular ethnic or religious groups.

Schools of the first type without an extended national language program do not collect books in minority languages. Neither do they have literature about ethnic groups that might be used to overcome potential bias against them, particularly in the communities where such groups exist.

In schools with an extended program of teaching the national language of a minority group and in schools attended only by minority group children ethnic literature should be proportional to other subjects, or make up the essential part of the collection. Complete 
data are not available with regard to the number of school libraries in institutions for national and ethnic minorities. Theoretically, there should be a library in each one. Unfortunately, it appears that this is not so, in particular with reference to newly-founded schools which have to use public library collections (this occurs in the Gdansk region where public libraries collect literature for children learning Kashubian). Nevertheless, on the basis of the actual increase in the numbers of schools for minorities (123\% growth in 1996/97 in comparison to $1994 / 95$ ) it can be extrapolated that the number of libraries in them will also grow. The book collections in the libraries of schools attended by minority group children are diversified both in quantity and in quality. As a rule, these libraries do not keep statistics on minority collections or register loans concerning the literature of ethnic groups so it is difficult to assess the readership of these groups of users.

Research carried out in the early 1990s (Wawulska, 1991, 128-129) showed that Belorussian collections existed in 45 primary schools and 2 secondary schools in the Bialystok region, the basic concentration of Belorussians, who were not moved away from their lands after 1945. In most of these libraries the collections were outdated and discouraged rather than attracted potential readers. The collections themselves were usually donations, which explains their random character. Few books were purchased purposefully. The size of a particular collection can vary from several dozen to a few thousand volumes. In primary schools they amount to about $5 \%$ of the whole collection. The number of books per one pupil attending Belorussian lessons ranges from 2.4 to 16 , while the average in Poland is 19.97 volumes per pupil (Jaroszewicz, 1994, 147). Collections in the national language made about $5 \%$ of the total in the primary schools and $12 \%$ in one secondary school. Most of them were donated, which explains their incidental character. The librarians in the schools with Belorussian as the language of instruction point out that lending books in this language is scanty and they are used mainly in language lessons.

A different situation is found among the Ukrainian minority. They are not concentrated geographically as the Belorussians are and can be found in many regions of Poland. Nevertheless, interest in the Ukrainian language is growing systematically, new schools are being built, and Ukrainian societies are very active disseminating national literature. They have their own WWW pages in the Internet. Schools, particularly the secondary ones, have access to this network so they can easily keep contact with one another, but also with their native country and with groups in USA and Canada, from where they get many books, including school books.

Of the minority school libraries the German ones seem to be in a relatively good situation. They are supplied with national literature better than others are. This is because books in German are available in Poland and many are donated by institutions in Cermany. As a minority they have access to a number of radio and TV programs, which is an additional advantage. Libraries in their schools use Internet often too, which fosters linguistic and cultural integration with German peers.

The other function of the book, which I mentioned earlier in this paper, i.e. the therapeutic function, together with the bibliotherapeutic program following from it, are worth presenting due to their potential for using them in the process of social integration, including multiethnic communities. With reference to the process of acculturation that can be observed among ethnic groups John Schumann (Schumann, 1981, 27-50) distinguishes three integration strategies: adaptation, preservation (particularly among geographically 
distributed minorities), and assimilation (particularly among emigrants). The book and bibliotherapy can play a very important role in each of the three strategies chosen by the given group. In spite of the new carriers of information the printed word is still the main instrument of acculturation. It can be a tool to fight negative stereotypes and to form tolerant attitudes towards others. It can help individuals function outside their own groups. Simultaneously, it enables people to develop knowledge about the group, nation, cultural heritage or national achievements that can be reasons for pride. The printed word also helps getting familiar with life and specificity of other national and ethnic groups, thus promoting better understanding and mutual relations. In addition, it can help overcome language barriers and cultural differences.

The book can and should also provide honest information about various ethnic groups. Without such information it is impossible to understand them or develop tolerant attitudes to and acceptance of other nations. Getting to know them will not only help develop mutual respect but will also enrich every individual's personality. It is indispensable to establish correct ideas concerning particular ethnic groups, as both good and evil people can be found in them. Transfer and dissemination of information about the achievements and culture of a group will weaken social ignorance and diminish mutual distance. Furthermore, the book and bibliotherapy can also be useful in founding positive attitudes of various groups to one another, in fighting xenophobia, i.e. aversion to other nations.

In its therapeutic function the book can help adequately understand the notion of otherness. To many individuals, in particular to children, 'another' is often a synonym of a worse, useless, undesired group of citizens. The book has its role to play here too: it can build self-esteem. Essential in this process is, however, acceptance of oneself, which will eventually result in being accepted by others. Lack of self-acceptance, individual inferiority complexes, and actual or imaginary awareness of one's own lesser worth can result in overseeing positive features in others, intolerance, and ultimately in aggression towards them.

These therapeutic possibilities of the book apply to all age groups. However, the greatest potential cumulates in the book addressed to the young reader who gets familiar with it in childhood. This is the period when not only knowledge is acquired, but also sentiments, resentments, and stereotypes are shaped in connection with the perceived and evaluated real world surrounding the young individual. They usually become firm and resistant to change, in spite of the child's development and education (Papuzinska, 1997, 174). It is then that attitudes and reactive behaviors form. Whether they will be appropriate or not depends to a large extent on the literature the child is provided with.

The political changes that took place in Poland within the last decade and the activity of national groups there resulted in the appearance of new problems that Polish educational institutions are faced with. Among the crucial ones are:

bringing the children and the youth of different cultural traditions close together,

establishing a dialogue among them,

overcoming barriers and bias,

developing positive attitudes towards one another.

In the countries where the tradition of friendly co-existence has been long these roles are performed by school and public libraries. In Poland, however, they are new so the relevant 
activities are innovative. An institution of great merit in realizing a program of developing mutual understanding among children of different nationality is the Children's Library in Auschwitz. Apart from its activities directed at children it also supports librarians in other libraries by giving vocational advice, providing methodological materials, lending exhibitions, and organizing seminars to which librarians from all over Poland are invited.

One of the first initiatives of the library, carried out together with the editors of the children's magazine Guliwer and the 'Books for Children Foundation' was the organization of the Children's Literature Forum of the Baltic Countries. Its leading theme was 'Information on the Children's Book - sources, methods, users' and the aim was initiating and arranging exchange of information concerning books for children. The initiated project was intended initially to present the real picture of a given neighboring country, followed by showing similarities and common features between it and Poland. A number of events and developments accompanied the project, which rose in the course of time.

Another initiative of this library was the organization of a mobile foreign language book exhibition 'At our southern neighbors" in June 1997. It was part of another project entitled 'Presentation of culture in other countries through the children's book' (J.M., 1997, 58). The exhibition included Czech and Slovak literature and was divided into 4 sections: i) histarical books; ii) Czech literature for children and the youth (including that with the well-known characters of Rumcajs, Cypisek, etc.); iii) Slovak books for children and the youth; iv) Polish translations of Czech and Slovak authors.

Another example of the initiative serving mutual understanding between children of different nationalities is an integrative Euro-nursery-school (Nowak \& Baranowski, 1998, 11) operating in Frankfurt on the Oder since 1997. German children from Frankfurt and Polish children from Slubice attend it. An opportunity to learn German and Polish as a second language by children was initially considered the main advantage of the school. However, it was soon realized that its essential advantage is forming in the children a positive, non-xenophobic way of thinking, an education in the atmosphere of understanding and tolerance. The children learn Polish and German songs, the literature of their countries, their culture and customs. There should be more such institutions along the border but, fortunately, the first step has been made.

Naturally, the book should conform to some requirements to be capable of fulfilling the functions discussed above and be of help in the acculturation process. First of all, it must not contain texts offensive to readers of different races or nations. It must avoid manifestation of discrimination and intolerance. Such acts, in J.Papuzinska's words 'concern not only discrimination declared expressis verbis but also symbolic texts that contain indirect implications of pejorative evaluations of minority groups or their behavior' (translation: E.B.Z.) (Papuzinska, 1991, 51). It should avoid not only antagonizing or disrespectful texts, but also those tinted by patronizing or superior attitudes towards any group or nation. Hence, the issue of censorship should also emerge as a relevant problem. It is especially significant for the publishers of books for children. This, however, is out of the scope of this paper.

Another problem posed by the therapeutic function of the book is appropriate assembling of collections intended for public use by children of various ethnic and cultural groups. 'While the purchase of a given book for an individual child is a matter of his parents' views, 
the public or school library has to meet the requirements set by the rules of ethnic group co-existence and be beyond accusation of possessing books that offend any reader's feelings. This implies the necessity of introducing library censorship, which has to be careful not to deprive the collection of valuable books that deal with controversial problems' (translation: E.B.Z.) (Papuzinska, 1991, 51). An important and valuable journal that advises librarians, teachers, and parents on the selection of books, on the organization of various library activities, including those of a multi-culture character, is The Guliwer (Eng. Gulliver) which has been published since 1990. Among other things, it presents international recommendations and tendencies that aim at popularizing and publishing valuable books for children, also those dealing with minority problems.

After the 2nd World War in Polish literature for children and the youth practically nothing was written about the Germans, Ukrainians, Belorussians, or Lithuanians living in Poland. This fact derived from the politically determined claims (already mentioned earlier) that Poland was a mono-ethnic country. Hence Polish children knew very little about their peers from other groups.

Before 1989 education was subordinated to political objectives and therefore children were informed about poor Blacks oppressed in America and of exterminated Indians tribes but not about the fate of the nations historically tied up with Poland and Poles (Papuzinska, $1997,174)$.

In the contemporary Polish literature relatively few characters appear who have other than Polish roots. However, books that depict stereotypes in viewing different groups are common. Although this refers usually to individuals, their negative features are generalized and ascribed to the group they come from. Consequently, such pejorative generalizations harm the whole group.

Some stereotypical pictures selected from Polish literature for children and adolescents are presented below. They concern Gypsies, Germans, and Jews.

Apart from the exotic attraction, the Gypsy makes an infrequent appearance in the children's book. The Cypsies are always mysterious and alien, always in conflict with the environment, confined in their own world. A whole gamut of suspicions, accusations, and dislikes has followed them for ages. A picture of a lazy bum, cheater, and thief emerges. Triteness like this leads to forming discriminating stereotypes, that function in literature and real life. Gypsies have been accused of having the wildest of instincts that they followed, e.g. to kidnap children. At present, the picture of the Gypsy has changed as a number of elements of the stereotype have lost their validity. Accusations have turned out irrational or ungrounded to be continued. The myth of the Gypsy-kidnapper and superstitions incited by the alleged Gypsy black magic have vanished. However, there is also a romantic thread in the literature: Gypsies are shown as mysterious wanderers, living a colorful, exotic life, following the laws of nature. The two stereotypes often mingle giving a version of ideas people have about Gypsies. Nonetheless, there are also books, like those by Maria and Jan Ziolkowski, which discredit prejudice, cite various opinions, and present the expectations of both sides. Their novels seem to represent all literary attempts at fighting against the Gypsy stereotypes (Dworakowska, 1995, 83).

In the recent children's literature the Gypsy theme, in fact rare, reflects the authors' more friendly attitude towards them. 
As regards Germans in the Polish literature for children stereotypes function, too. As is known 'although in the history of our mutual relations they were good and bad, the period during which children's literature developed, i.e. the 19th and 20th centuries, was characterized by hostility. Therefore the stereotype of the German nation in children's literature is negative: that of the aggressor and occupant, in which the military aspect of the relations is highlighted. However, the stereotype of the German-eternal enemy is linked, at least in the literature appearing before 1945, with admiration for his resourcefulness, diligence, ability, and respect for order as opposed to Polish national faults (translation: E.B.Z.) (Papuzinska, 1996, 102). Naturally, Germans do not make a monolithic picture. There are good Germans - the Bavarians, and bad Germans - the Prussians. After the war the distinction was applied according to German citizenship. The position of the 'good Bavarians' was taken by the 'good East Germans' of the German Democratic Republic, the Prussians by the inhabitants of West Germany (including the Bavarians, of course). Stereotypes of the sort are really rare now. However, due to certain magazines for young readers, e.g. Bravo or Dziewczyna (The Girl) another stereotype of a young German is being formed, just as harmful. It is the picture of liberated youngsters, devoid of intellectual ambitions, uninterested in any system of moral values, conformist, indulging in free love. Their preferences being a career crowned with big money, consumerism, liberty and independence.

Representatives of the Jewish minority appear in the Polish literature for children relatively seldom and the picture is not inconsistent. What is characteristic for this stereotype, however, to ascribing to the picture of a lew the role of a victim. He is harmed and persecuted by others also by people from various national groups, but is defended by the Polish child (Papuzinska, 1996, 105). This picture contains also other elements: the Jew is shrewd, gifted, in particular endowed with artistic talents. These features are less emphasized than the ones mentioned before, i.e. defenselessness and helplessness. Such a picture is, certainly, one-sided and biased. Unfortunately, no translations of Israeli or Jewish literature for children have been made into Polish after the War to counterbalance the stereotype.

Discussing the content of the children's literature from the point of stereotypes it seems worth pointing to the investigations carried out by a team at the Pedagogical University in Opole (Weigl \& Lukaszewicz, 1992). They analyzed school textbooks and magazines for children to see how Poles and foreigners, and Poland and foreign countries are presented in them. They concluded that the school and the literature contribute to strengthening and copying stereotypes, whether positive or negative, instead of presenting an objective picture of a given group. The research was done in Opole, where a substantial number of inhabitants claim their German origin, i.e. in the potential area of ethnic conflict. On the basis of the findings the researchers elaborated a project to help schools prevent ethnic prejudice. It consist of psychological games in which children learn to be tolerant and adopt positive attitudes towards athers. The objective of these games and similar activities is making the participants aware that every ethnic or national group consists of different individuals, both good and evil, and that individual differences or traits cannot be generalized and ascribed to the whole community or group.

Non-fiction is well represented by a volume entitled The traditions of annual holidays, which appeared on the market only a few months ago in a series devoted to showing how 
people used to live in old Poland (Zadrozynska, 1997). It is a publication addressed to children, richly illustrated, describing traditional customs followed by different ethnic and national groups that used to or still live in Poland. Holidays of such ethnic groups as Polish Gypsies, Jews, Tartars and of religious groups as the Orthodox or Greco-Catholic are brought closer to the young reader in a simple, comprehensible language. Simultaneously, the reader's attention is drawn not only to how the customs and rituals were established, but also to the fact that many of them have permeated into our present customs and that they make common heritage of all people living in Poland.

The picture that emerges from the review presented above indicates that the situation of the book for ethnic minorities in Poland is not satisfactory. It is evident that improving it is indispensable, especially with regard to the education that aims at friendly coexistence of different groups and at doing away with anger and aggression common among children. Research indicates that raising the level self-assessment can diminish negative attitudes and behaviors (Duszynski \& Zagrodzka, 1997, 36). The level of self-assessment, which is neurophysiologically determined by the level of serotone in the brain, can be raised either pharmacologically by fluoxetine, known on the market as Prozac or by means of the written word. The book is certainly healthier. In addition, it is also educational and everyone can get it without a doctor's prescription.

\section{References}

Aleksander, Z. (1992). Problemy jezykowe i edukacyjne na Kaszubach $w$ swietle socjolingwistyki. In Problemy statusu jezykowego kaszubszczyzny. Materialy z sesji popularnonaukowej 17.X.1991. (pp. 58-69). Gdansk: Wojewodzki Osrodek Kultury. Zrzeszenie Kaszubsko-Pomorskie.

Charytoniuk, G. (1996). Literatura bialoruska w Polsce. Bibliografia przekladow za lata 1945-1994. Bialystok: Bialoruskie Stowarzyszenie Literackie Bialowieza.

Duszynski, J. \& Zagrodzka, J. (1997). Skad w nas tyle agresji? The Gazeta Wyborcza 36 (Supplement) , 36-37.

Dworakowska, B. (1995). Postac Cygana w polskiej literaturze dla dzieci i mlodziezy. Unpublished M.A. dissertation. University of Warsaw.

Ginzberg, L. (1997). Legendy zydowskie. Warszawa: Cyklady

Hollender, H. (1995). Stan badan nad funkcjonowaniem ksiazki w grupach etnicznych w Polsce. In Ksiegozbiory obcojezyczne. Dzialalnosc bibliotek publicznych na rzecz mniejszosci narodowych. Materialy z sesji. Opole-Kamien Slaski 25-26.11.1994. (pp.49-63). Opole: Wojewodzka Biblioteka Publiczna.

Jaroszewicz-Piereslawcew, Z. (1994). Mniejszosc bialoruska w Polsce. Wybrane problemy. In: W.Pilat (Ed.), W kregu kultury bialoruskiej. (pp.133-151). Olsztyn: Wydawnictwo WSP.

J.M. (1997). Z Biblioteki w Oswiecimiu. Guliwer, 6, 58

Materialy statystyczne Centrum Obliczeniowego MEN. (1997). Warszawa: MEN. Unpublished report of the Ministry of National Education. 
Mniejszosci narodowe w Polsce. Informator 1994. (1995). Warszawa: Wydawnictwo Sejmowe.

Na przeleczy swiatow.150 ukrainskich basni, gadek, humoresek i podan ludowych. (1994). Ed \& transl. J.M. Kasjan. Torun: Wydawnictwo Uniwersytetu M.Kopernika.

Nowak, W. \& Baranowski, D. (1998). Idzie Macius przez granice. The Gazeta Wyborcza, 5.2.1998 no 302626, pp.10-11.

Papuzinska, J. (1997). Polska-Litwa: zblizenie przez ksiazke dziecieca. (Z doswiadczen biblioteki dzieciecej w Oswiecimiu). Lithuania 3-4, 174-178.

Papuzinska, J. (1996). Dziecko w swiecie emocji literackich. Warszawa: Wydawnictwo Stowarzyszenia Bibliotekarzy Polskich.

Papuzinska, j. (1991). Ksiazka dziecieca w grupach zroznicowanych etnicznie. In A.Skrzypczak (Ed.), Ksiazka i czytelnik w grupach etnicznych (pp. 46-53). Warszawa: Instytut Bibliotekoznawstwa i Informacji Naukowej UW.

Schumann, J.H. (1981) The acculturation model for second-language aquisition. In R.C. Gingras (Ed.), Second language acquisition and foreign language teaching (pp. 27-50). Washington, D.C.: Center for Applied Linguistics.

Veigl, B \& Eukaszewski, W. (1992): Uprzedzenia i stereotypy etniczne u dzieci; przeciwdzialanie i modyfikacja. Unpublished report of the Higher Pedagogical School in Opole.

Wawulska, D. (1991). Ksiegozbiony bialoruskie w wojewodztwie bialostockim. In A.Skrzypczak (Ed.), Ksiazka i czytelnik w grupach etnicznych (pp.126-130). Warszawa: Instytut Bibliotekoznawstwa i Informacji Naukowej UW.

Zadrozynska, A. (1997). Tradycje swiat dorocznych. Wroclaw: Wydawnictwo Dolnoslaskie.

Zaniewska, T. (1992). Podrcz daremna. Szkice o poezji bialoruskojezycznej w Polsce. Bialystok : Bialoruskie Stowarzyszenie Literackie Bialowieza. 